\begin{tabular}{lrr} 
Jurnal Pendidikan Dasar Perkhasa & \\
http://jurnal.stkippersada.ac.id/jurnal/index.php/JPDP/ & P-ISSN 2461-078X \\
& E-ISSN 2654-783X \\
& JPDP 7 (1) (2021) 35-46 & DoI: 10.31932/jpdp.v7i1.1033 \\
\hline
\end{tabular}

\title{
PENGEMBANGAN MATERI TEMATIK RAGAM SENI KARYA DENGAN GAMES PUZZLE UNTUK MENGASAH OTAK ANAK PADA SISWA KELAS RENDAH MI NW LINGKOK TELU
}

\author{
Hamzani Aulia Rahman*1, Aninditya Sri Nugraheni2 \\ 1,2Pendidikan Guru Madrasah Ibtidaiyah, Universitas Islam Negeri Sunan Kalijaga Yogyakarta \\ Diterima: 13 Januari 2021. Dipublikasi: 30 April 2021.
}

\begin{abstract}
This research aims to give learners a stimulus about the variety of art in thematic which is one of the sustainable material models with various descriptions in local traditions and wisdom in the community by explaining the various understandings and history in it with facts and concepts later in order to hone their brains about culture. Research method in this ha used is Waterfall Research and Development model with stages ranging from analysis, design, implemntasi and testing and the end of maintenance. Then the results of the study showed from the material content test or produck got an average of $75.6 \%$ with a decent category then researchers tried the test and implementation to students numbering 10 people and got an average of $81.6 \%$ categorized into satisfaction with a score of 80 in the category agreed. Therefore, it can be concluded that puzzle media for learning facilities in sharpening the brain of learners can improve their abilities and make learning fun.
\end{abstract}

Keywords: Variety of Works Art, Puzzle Games. Sharpening the Brain.

Abstrak. Penelitian ini bertujuan untuk memberikan peserta didik stimulus tentang Ragam seni dalam tematik yang merupakan salah satu model materi yang berkelanjutan dengan berbagai gambaran dalam tradisi dan kearifan lokal di masyarakat dengan menjelaskan berbagai pengertian dan sejarah didalamnya dengan fakta dan konsep kemudian dalam rangka mengasah otaknya tentang budaya. Metode penelitian dalam ha ini yang di gunakan adalah Research Dan Development model Waterfall dengan tahapan mulai dari analisis, design, implemntasi dan pengujian serta bagian akhir pemeliharaan. Kemudian hasil penelitian menujukkan dari uji isi materi atau produk mendapatkan rata-rata nilai $75,6 \%$ dengan di kategorikan layak selanjutnya peneliti mencobakan pengujian dan implementasi kepada peserta didik berjumah 10 orang dan mendapat rata-rata sebesar $81,6 \%$ yang dikategorikan ke dalam kepuasan dengan nilai 80 dalam kategori setuju. Maka dengan itu dapat disimpulkan bahwa media puzzle untuk sarana belajar dalam mengasah otak peserta didik dapat meningkatkan kemampuannya serta menjadikan permbelajaran menjadi menyenangkan.

Kata kunci: Ragam Seni Karya, Games Puzzle. Mengasah Otak.

\section{Pendahuluan}

Perkembangan adalah suatu yang menonjol dalam manusia tak terkecuali inovasi dalam ilmu pengetahuan, Pendidikan menjadi sarana dalam mengembangkan suatu ilmu pengetahuan bagi guru pengembangan menjadi suatu yang mutlak dilakukan guna memberikan suatu perubahan dalam memudahkan 
proses belajar (Estiningtyas, 2015). Akan tetapi dalam banyak hal guru mempunyai keluhan dalam proses aktualisasi Pendidikan tersebut misalnya prasana yang memadai dan kecukupan waktu dalam proses pembelajaran (Abdulah, 2019). Karena itu, pengembangan menurut banyak ahli merupakan suatu kemudahan dalam penerapannya (Afrian \& Arifin, 2018).

Di era serba digital dan keluasan menerima informasi banyak model Pendidikan yang mengarah pada pemamfaatan teknologi dan terdapat metode - metode yang berkenaan atau menempel pada teknologi itu. Jadi pada pengagalan wacana atau konstruksi dalam artian pengembangan harus berkenaan dengan perubahan zaman karena tanpa melihat kondisi lingkungan dalam penerapan suatu Pendidikan maka dalam prosesnya dan outputnya menuai kemunduran dan tentu saja assessment dalam keluasan masyarakat menjadi memudar oleh karena itu perlu bagi seorang guru untuk tetap berinovasi dalam pembelajaran sehingga terjaminnya sumber manusia yang mampu berkemampuan dalam ranah global (Semiawan, 2017).

Kemampuan otak dalam arti ranah kognitif pada manusia merupakan seorang yang memiliki potensi untuk berkembang di sertai pengetahuan hampir tak terbatas (Aldarmono, 2012). Kemudian fungsi kecerdasan otak sebagai sarana memperlancar tercapainya sebuah pemahaman dalam membaca, mendengar dan melihat serta melakukan aktivitas yang berkenaan dengan tujuannya. sedangkan menurut sujiono fungsi dan tujuan dari media sebagai alat pembantu dalam kemampuan otak dalam ranah kognitif adalah untuk merangsang, bereksperimen, berimajinasi dan melatih kepekaan dalam berpikir (Fitria, 2019).

Anak mempunyai ciri yang aktif dan berkembang. Kebutuhannya menonjol dengan dipenuhi melalui permainan, baik dengan individual ataupun kelompok. maka, bermain bagi anak merupakan sebuah nilai penting baginya. Dalam buku Child Care \& Education dikatakan "setiap anak di dunia ini mempunyai hak untuk bermain"(Bruce, Meggitt, \& Grenier, 2010). Para Ahli Pendidikan 
menganggap Bermain adalah salah satu cara untuk belajar secara informal menjadi formal di karenakan bermain sebagai kaktivitas yang mempunyai nilai praktis terlebih digunakan sebagai media untuk meningkatkan keterampilan dan kemampuan tertentu pada anak.

Aktivitas bermain untuk pengembangan keahlian anak telah disadari oleh para pakar filsafat semacam Plato ataupun Aristoteles. Aristoteles berkomentar kalau kanakkanak butuh didorong buat bermain dengan apa yang hendak mereka tekuni pada waktu berusia nanti. Dengan demikian bermain untuk anak hendak mendapatkan pengetahuan serta pengalaman yang menolong perkembangannya buat mempersiapkan diri dalam kehidupan berikutnya. Lewat aktivitas bermain anak dapat menggapai pertumbuhan berbagai macam. Game memberikan sumbangan besar pada pertumbuhan anak didik, lewat game kanak- kanak belajar tentang gagasan - gagasan, tentang hubungan komunikasi (Agiatama \& Santoso, 2019). Bermain bukan cuma jadi kesenangan namun pula sesuatu kebutuhan yang ingin tidak ingin wajib terpenuhi, sebab bila tidak terpenuhi bagi conny $\mathrm{R}$. Semiawan terdapat sesuatu tahapan pertumbuhan yang berperan kurang baik yang hendak nampak nanti bila sianak telah jadi remaja (Semiawan, 2017).

Pada pembelajaran tematik yang menyangkut dalam banyak materi terdapat materi seni kriya, seni dalam artian sebuah keterampilan dan kriya dalam pengetahuannya mampu menciptakan bentuk dalam imajinasi. Sehubungan dengan materi seni karya banyak model berbentuk gambar dan hanya dilihatkan oleh seorang guru ke peserta didik dan dalam praktiknya murid masih sulit untuk membuat semacam pada gambar (Maulida, 2020), atau siswa masih menerka dalam gambar mulai dari asal usul, bahan, serta dari mana kebudayaan itu berasal dari sebuah karya maka bagi peneliti itu kurang tepat dalam pemamfaatan materinya dan ini pula yang terjadi pada madrasah ibtidaiyah nw lingkok telu yang notabennya dalam materi seni karya siswa sulit sekali menerka dan memberikan jawaban apabila ditanya tentang gambar-gambar tentang budaya mulai dari mana asal usulnya, diolah dari apa? dalam materi seni karya 
alangkah baiknya seorang guru dapat juga berimajinasi untuk membuat suatu terapan dalam mengusahakan pola berpikir anak misalnya permainan (Pitriani, 2020), pada dasarnya permainan hanya suatu kesenangan semata atau untuk menghibur diri maka dalam penerapan pendidikannya. Arti puzzle dalam Bahasa inggris adalah teka teki yang dalam artian permainan Menyusun keping - keping dalam potongan benda yang kurang utuh untuk disempurnakan baik itu berupa bentuk atau gambar. Sedangkan mamfaat permainan sebagai permainan edukatif untuk meningkatkan keterampilan perkembngan kognititif, aktif, psikomotorik (Lusiawati, 2019). Kemudian dalam jenis permainan puzzle terdapat 5 macam sifat dalam melihat permainannya antara lain logic, jigsaw, mechanical, contruction, combination. Maka, Menurut Anggani Sudono dan Agus Heriyanto puzzle ialah salah satu permainan yang bisa dimasukkan dalam pendidikan dan dapat di gunakan pada anak untuk belajar serta mengikatkan daya ingat anak (Lusiawati, 2019).
Peneliti ingin berupaya membuat suatu permaian dalam bentuk puzzle untuk mengasah otak anak dalam pembelajaran pada materi seni karya dalam bentuk pengertian seni rupa dalam gambar $3 \mathrm{D}$ dan dengan tujuannya ingin melihat peserta didik bukan hanya melihat gambar tersebut tapi juga bermain dan dapat juga membentuk pola gambar mereka dalam bentuk pecahan-pecahan yang masih kurang lengkap dalam pikirannya. Maka dari itu peneliti ingin melihat pengembangan game edukasi puzzle dapat mengasah otaknya berpikir pada anak kelas rendah.

\section{Metode}

Jenisnya peneliti menggunakan metode Research and Development (R\&D) yang secara sederhana yaitu metode penelitian yang digunakan untuk menghasilkan produk dan menguji produk tersebut untuk diterapkan. Penelitian pengembangan juga sering dilakukan sebagai penelitian formatif dan dapat juga studi membangun ulang, namun belum menghasilkan produk atau model yang lengkap (A. Muri Yusuf, 2016). Model pengembangan 
diistilahkan suatu proses atau kuantitatif (Creswell, 2014, p. 293). langkah-langkah dalam Adapun urutan mekanisme dan mengembangkan produk baru atau langkah-langkah penelitian menyempurnakan produk yang telah pengembangan pada bidang ada dengan mengkombinasikan data pendidikan model waterfall dapat dilapangan baik kualitatif dan dilihat pada Gambar 1.

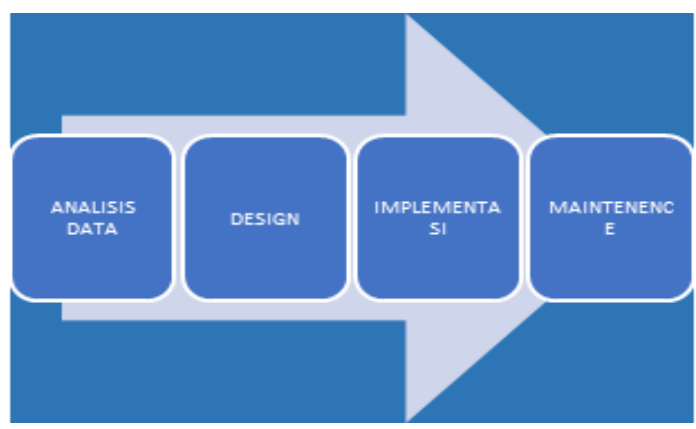

\section{Gambar 1. Langkah Penelitian Model Waterfall}

1) Analysis Data: pada tahap ini peneliti mengumpulkan data kemudian dianalisis Untuk kebutuhan peneliti. Maka dalam tahap ini peneliti melakukan observasi, wawancara, serta mengidentifikasi masalah yang ada di MI NW Lingkok Telu kelas 3. Permasalahan yang ditemukan yaitu kurang bentuk pengembangan materi seni karya yang ditransformasikan dalam bentuk elektronik.

2) Design: Pada tahapan ini peneliti mendesain terlebih dahulu menentukan gambar yang tepat dengan materi seni rupa yang terkait dalam buku paket, kemudian menentukan aplikasi/media yang akan digunakan adalah system android melalui pengembangan website ninja apps dengan (serangkaian gambar yang terpecah berbentuk jigsaw).

3) Implementasi dan Pengujian: pada tahapan ini yang pertama peneliti melakukan penyiapan berupa bahan yang akan digunakan dalam membuat game puzzle yakni dengan menggunakan gambar gambar budaya yang sudah ada di source internet kemudian untuk bahan - bahan lain yang menunjang sudah disediakan pleh 
pihak pengembang apps ninja maka proses pengujian dirunut menjadi 2 yaitu (a) Kelayakan produk (b) Pengujian Keefektifan suatu produk. Pengujian kelayakan dilakukan oleh para guru bersangkutan dalam mengajar untuk mengetahui layak atau tidaknya media digunakan, setelah itu dilakukan pengujian kedua yaitu pengujian keefektifan yang dilakukan pada MI NW Lingkok Telu kelas 3 dengan subjek penelitian random yakni berjumlah 10 orang. Tahap kedua ini dilakukan untuk mengetahui hasil peningkatan kemampuan berpikirnya peserta didik menggunakan pertanyaan pertanyaan terkait isi materi dalam media tersebut.
4) Pemeliharaan (Maintenance): pada tahapan terakhir ini perangkat lunak yang sudah berbentuk menjadi produk di kembangkan lagi yang dalam artian bahwa Pemeliharaan adalah suatu perbaikan sistem sesuai dengan kebutuhan pada materi pembelajaran (Helsa \& Arlis, 2020, p. 51).

Teknik pengumpulan data awal peneliti menggunakan observasi dan wawancara untuk menganalisis masalah yang ada pada kelas. Kemudian untuk mengetahui keefektifan peneliti menyebarkan angket yang di ukur dengan skala Likert pada SPSS untuk mengetahui jawaban pada kelayakan produk yang diberi skor ketetapan seperti terlihat pada Tabel 1 (Sugiyono, 2008).

Tabel 1. Kriteria penilaian

\begin{tabular}{ll}
\hline Persentase & Kriteria \\
\hline $81,25>100$ persen & Sangat baik \\
$62,50>81,25$ persen & baik \\
$43,75>62,50$ persen & Cukup \\
$<43,75$ persen & Kurang \\
\hline
\end{tabular}

\section{Hasil dan Pembahasan}

Hasil produk pengembangan game puzzle sebagai pengasah otak dibagi menjadi 2 yaitu: (1) Game edukasi yang digunakan untuk mampu berinteraktif dengan pemain dan mampu memberikan pengalaman dalam meyelesaikan game (Wulandari, Susilo, \& Kuswandi, n.d., p. 5). (2) Media pembelajaran game ini digunakan sebagai wadah dalam berpikir dari game edukasi yang telah 
dibuat (Mulyana \& Nasrudin, 2015, p. pembelajaran yang telah dibuat 95). Berikut ulasan game edukasi seperti terlihat pada Gambar 2. untuk mendukung media

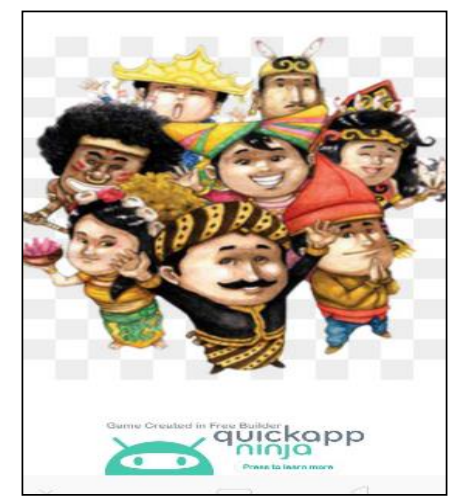

\section{Gambar 2. Penampilan Game Puzzle Awal Memulai Game}

Tampilan materi, pada layar ini menjelaskan tentang permulaan dengan cara menggeserkan gambar sesuai pola yang benar pada gambar transparan di slide selanjutnya dengan menunggu beberapa saat. Tampilan game ini terdapat gambargambar dengan seni kriya dari berbagai daerah yang terhimpun dalam potongan-potongan gambar kecil kemudian menjawab pertanyaan dengan clue satu potongan akan mengurut atau menempel pada bagan kolom yang sudah disiapkan. bagaimana cara bermain dengan benar. Tampilan disajikan pada Gambar 3.

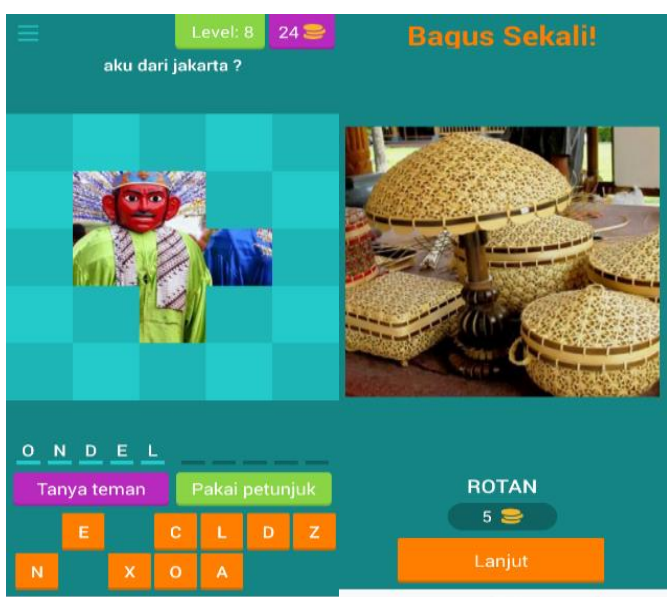

Gambar 3. Tampilan dalam Bermain 
Tampilan game scene kedua ini berisikan gambar-gambar seni kriya yang telah dimasukkan dalam 2 bagian dimana bagian sebelah atas berisi gambar yang terpecah dan tersembunyi dengan berbagai macam bentuk guna untuk menjawab pertanyaan dari bentuk gambar puzzle yang sudah terpotong pada bagian sebelah bawah tersebut.

Adapun karakteristik dari game mulai dari awal level sampai akhir akan dipaparkan seperti pada Tabel 2 .

Tabel 2. Pertanyaan dalam Game

\begin{tabular}{ll}
\hline Pertanyaan aplikasi & Jawaban \\
\hline tari apakah ini? & Pendet \\
bumi shambara nama lain? & Borobudur \\
dari bahan apa aku dibuat? & Rotan \\
kesenian dari jogja? & Batik \\
Kesenian dari ponorogo? & Reog \\
aku dari jakarta? & OndelOndel \\
tarian dari aceh? & Saman \\
tarian dari papua? & Sajojo \\
pertunjukan boneka? & Wayang \\
alat musik ini apa? & Angklung \\
alat musik pukul tangan? & Gendang \\
aku dibuat dari tanah.... & Liat \\
\hline
\end{tabular}

\section{a. Validasi Guru}

Validasi ahli materi, dilakukan
Hasil validasi media disajikan pada Gambar 4.

oleh guru kelas.

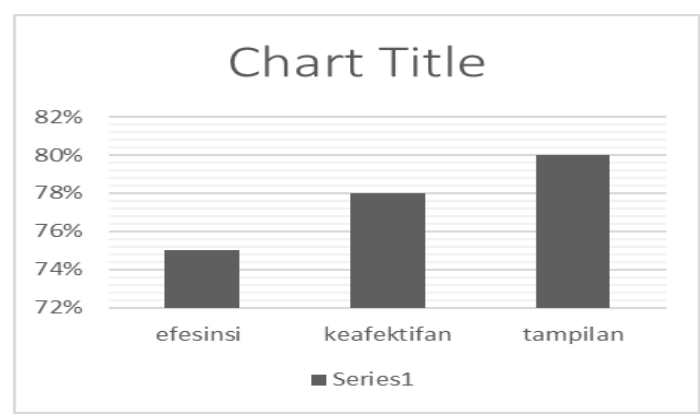

Gambar 4. Grafik Hasil Validasi

Hasil Validasi Materi yang dimuat pada diagram tersebut, dikatakan bahwasannya untuk penilaian dari ahli materi yakni guru kepada semua aspek yang diujicobakan mendapatkan rata rata nilai untuk kategori baik. Menurutnya pada aspek efisiensi dengan nilai $75 \%$ yakni isi atau modelnya baik, kemudian pada 
aspek keafektifan sebesar 78\% dalam penyajian materi sangat membantu karena bisa di rubah sesuai dengan kebutuhan yang ada di buku atau materi lain, dan pada tampilan mendapat $80 \%$ hal ini di karenakan media sangat memudahkan dalam memahami kalimat pada teks, Penggunaan bahasa yang mudah dipahami sudah baik dan keselarasan game edukasi dalam memperjelas contoh seni karya bisa digunakan. Maka Dapat disimpulkan bahwa game edukasi puzzle sebagai media mengasah otak dapat digunakan untuk menciptakan stimulus dalam motivasi dan perkembangan otak (Lestari, Sahputra, \& Hadi, n.d.).

\section{b. Uji Coba Terhadap Peserta didik}

Uji coba ini dilaksanakan secara random dengan percobaan 10 siswa. Untuk model penilaiannya peneliti menyebarkan angket berbentuk koesioner terhadap peserta didik guna mengetahui respons dari peserta didik pada permainan edukasi puzzle yang telah diuji. Aspekaspek yang ada pada angket tersebut meliputi: aspek kemamfaatan, kemudahan, kemenarikan, motivasi. Hasil semua penilaian dilakukan peserta didik tersaji pada Tabel 3.

Tabel 3. Nilai Kepuasan Peserta Didik

\begin{tabular}{ccccc}
\hline No & Aspek & Siswa & Nilai & Kategori \\
\hline 1 & Motivasi & 10 & $81.30 \%$ & sangat baik \\
2 & Kemenarikan & 10 & $75.60 \%$ & baik \\
3 & Kemudahan & 10 & $85.73 \%$ & sangat baik \\
4 & Pemamfaatan & 10 & $85.10 \%$ & sangat baik \\
\hline & Jumlah & & $\mathbf{8 1 , 9 3 \%}$ & setuju \\
\hline
\end{tabular}

Berdasarkan hasil respon dari peserta didik yang dapat dilihat pada diatas, bahwa hasil diuji cobakan mendapat nilai cukup baik yakni sebesar 81,93 \% yang dikategorikan ke dalam kategori setuju. Hasil respon mereka kepada media pembelajaran berbasis game puzzle yang pengembangannya paling menonjol yakni tertinggi pada aspek kemudahan, menurut mereka penggunaan media puzzle untuk belajar dan mengasah otak dengan media berbentuk game edukasi dapat diterima dengan baik dan penggunaan media 


\begin{abstract}
pembelajaran ini dikategorikan didik dalam melaksankan cukup menyenangkan bagi nya karena dalam game tersebut siswa di tuntut untuk mengolah dan mengurut kata - kata sesuai dengan potongan gambar yang sudah menjadi kisi - kisi nya.

Kelayakan

dalam

mengembangkan media pembelajaran

pembelajaran serta menumbuhkan minat serta kerja otak mereka (Jabar, n.d.). Maka dapat simpulkan bahwa media pembelajaran ini efektif digunakan untuk meningkatkan kemampuan berpikir siswa pada materi seni karya yang disesuaiakan dengan bahan ajar di kelas.
\end{abstract} harus diuji dengan berbagai tahap maka dalam mengetahui kelayakan terdapat dua aspek utama yang memang sering digunakan yakni pertama kelayakan ekonomi dan kedua kelayakan teknis (Khoriri, Murtiyasa, Kom, \& Sukirman, 2018) Untuk itu perlu dimaknai bahwa "apakah suatu produk atau ide dapat di realisasikan dalam keadaan tertentu sesuai dengan kebutuhan". Untuk itu pada penelitian ini pengujian menggunakan dua aspek yaitu: validasi guru dengan memperoleh rata - rata nilai sebesar 78\% dengan kategori layak kemudian dilanjutkan dengan uji coba ke peserta didik dan medapatkan nilai 81.93\% pada kategori setuju digunakan dalam media pembelajaran. Pernyataan itu sesuai dengan tujuan dari permainan digital berbasis teknologi yakni untuk dapat lebih memudahkan peserta

\section{Simpulan}

Dari hasil kajian yang sudah dipaparkan diatas bahwa game puzzle bergambar layak digunakan dalam memberikan treatmen kemampuan berpikir. Hal ini tergambar dari hasil pengujian dari guru sebagai ahli materi dan responden dengan 10 peserta didik sehingga dalam pelaksanaannya termasuk dalam kategori layak. maka game edukasi puzzle sebagai media belajar mampu mengasah otak secara efektif dan digunakan untuk meningkatkan motivasi belajar yang bernuansa menghibur serta menyenagkan.

\section{Daftar Pustaka}

Abdulah, T. (2019). Pengembangan Media Pembelajaran Game Puzzle Terhadap Hasil Belajar DasarDasar Konstruksi Bangunan Siswa Kelas $\quad X \quad S M K N \quad 1 \quad \ldots$ 
repository.upi.edu. Retrieved from

http://repository.upi.edu/id/epr int/37301.

Afrian, P., \& Arifin, F. (2018). Pengembangan Permainan Puzzle Sebagai Media Pembelajaran Algoritma Pada Mata Pelajaran Pemrograman Dasar Kelas Xdi Smk Negeri 1 Magelang. Jurnal. Https://Eprints. Uny. Ac. Id/59239/1 ..., $(1$ cites: https://scholar.google.com/scho lar?cites $=321282117131619495$ $6 \&$ as_sdt $=2005 \&$ sciodt $=0,5 \&$ $\mathrm{hl}=\mathrm{en}) . \quad$ Retrieved from https://eprints.uny.ac.id/59239 /1/Naskah\%20Skripsi.pdf.

Agiatama, A., \& SANTOSO, A. B. (2019). Pengembangan Perangkat Pembelajaran Model Pembelajaran Kooperatif Tipe Teams Games Tournament (TGT) Dengan Permainan .... Jurnal Pendidikan ..., (1 cites: https://scholar.google.com/scho lar?cites $=625266781484503887$ \& as_sdt $=2005 \&$ sciodt $=0,5 \&$ $\mathrm{hl}=\mathrm{en})$. Retrieved from https://jurnalmahasiswa.unesa. ac.id/index.php/jurnalpendidikan-teknikelektro/article/view/27543

Aldarmono, A. (2012). Identifikasi Gaya Kognitif (Cognitive Style) Peserta Didik Dalam Belajar. AlMabsut: Jurnal Studi Islam dan Sosial, 3(1), 63-69.

Bruce, T., Meggitt, C., \& Grenier, J. (2010). Child care \& education: Tina Bruce, Carolyn Meggitt, Julian Grenier (5th ed). London: Hodder Education.
Creswell, J. W. (2014). Research design: Pendekatan Metode Kualitatif, Kuantitatif, dan Campuran (Edisi ke 4). Yogyakarta: Pustaka Pelajar.

Estiningtyas, N. N. (2015). Analisis Kesesuaian Buku Ajar Tema Indahnya Kebersamaan Kelas IV SD Dengan Kurikulum 2013. 6.

Fitria, N. (2019). Pengembangan Media Permainan Puzzle 3 Dimensi Sebagai Upaya Mengembangkan Kognitif Anak Usia Dini di Taman Kanak-Kanak .... Retrieved from http://repository.radenintan.ac.i d/8519/1/SKRIPSI.pdf

Helsa, Y., \& Arlis, S. (2020). Seminar Ke SD-An (Dalam Pendidikan Tinggi Untuk Penulisan Skripsi Dan Tesis). Deepublish.

Jabar, F. A. (n.d.). The Application of Online Games As Learning Tools In Education. 7.

Khoriri, F., Murtiyasa, B., Kom, M., \& Sukirman, S. (2018). Pengembangan Media Pembelajaran Berbasis Game Puzzle Bergambar untuk Meningkatkan Keterampilan Membaca dan Menulis Kelas 1 Sekolah Dasar. eprints.ums.ac.id. Retrieved from http://eprints.ums.ac.id/id/epri nt/69512

Lestari, Y., Sahputra, R., \& Hadi, L. (n.d.). Pengembangan Chemistry Puzzle (Chempuz) Pada Materi Tata Nama Senyawa Kimia di SMA Negeri 10 Pontianak. Jurnal Pendidikan Dan Pembelajaran .... Retrieved 
https://jurnal.untan.ac.id/index. php/jpdpb/article/view/40350

Lusiawati, I. (2019). PENGEMBANGAN OTAK DAN OPTIMALISASI SUMBER DAYA MANUSIA. Jurnal TEDC, (Query date: 2021-01-10 08:14:03). Retrieved from http://ejournal.poltektedc.ac.id/ index.php/tedc/article/view/74

Maulida, U. (2020). Pembelajaran Gambar Bentuk Bagi Siswa Kelas IV SD Inpres Paccerakkang Kota Makassar. JURNAL IMAJINASI, 4(1), 1-14. https://doi.org/10.26858/i.v4i1. 13114

Mulyana, A., \& Nasrudin, N. (2015). Games Puzzle Hijaiyah Elektronik Interaktif Berbasis Mikrokontroler DT-AVR Maxiduino. Scientific Journal of Informatics, 1(1), 95-105. https://doi.org/10.15294/sji.v1i 1.3644
Pitriani, S. (2020). Analisis Materi Pokok Seni Budaya Dan Prakarya (SBdP) Kelas III MI/SD. AULADUNA: Jurnal Pendidikan Dasar Islam, 7(1), 60. https://doi.org/10.24252/aulad una.v7i1a6.2020

Semiawan, C. R. (2017). Strategi Pengembangan Otak. Elex Media Komputindo.

Sugiyono. (2008). Metode penelitian pendidikan: (Pendekatan kuantitatif, kualitatif dan $R \& D$ ). Bandung: Alfabeta.

Wulandari, R., Susilo, H., \& Kuswandi, D. (n.d.). Multimedia Interaktif Bermuatan Game Edukasi Sebagai Salah Satu Alternatif Pembelajaran IPA di Sekolah Dasar. 8.

Yusuf, A. M. (2016). Metode Penelitian Kuantitatif, Kualitatif \& Penelitian Gabungan. Prenada Media. 